\title{
Evaluation of Knowledge, Attitude and Behaviour on Oral Health Through COVID-19 Pandemic
}

\section{COVID-19 Salgını Sürecinde Ağız ve Diş Sağlığına Ilişsin Bilgi, Tutum ve Davranışların Araştırılması}

\author{
(D) Zeynep Hale Keleş${ }^{1}$, (D) Hande Şar Sancaklı² \\ ${ }^{1}$ İstanbul Atlas University Faculty of Dentistry, Department of Restorative Dentistry, İstanbul, Turkey \\ ${ }^{2}$ istanbul University Faculty of Dentistry, Department of Restorative Dentistry, İstanbul, Turkey
}

Keywords

COVID-19, quarantine, oral health, oral hygiene, public health dentistry, nutritional surveys

\section{Anahtar Kelimeler}

COVID-19, karantina, ağız ve diş sağlığı, ağız hijyeni, toplum diş hekimliği, beslenme araştırmaları

Received/Geliş Tarihi : 21.07.2020

Accepted/Kabul Tarihi : 02.10.2020

doi:10.4274/meandros.galenos.2020.60352

Address for Correspondence/Yazışma Adresi: Zeynep Hale Keleş Asst. Prof., İstanbul Atlas University Faculty of Dentistry, Department of Restorative Dentistry, İstanbul, Turkey

Phone : +90 5352314777

E-mail : halekeles@hotmail.com

ORCID ID: orcid.org/0000-0003-3793-4512

(C) Meandros Medical and Dental Journal, Published by Galenos Publishing House.

This is article distributed under the terms of the

Creative Commons Attribution NonCommercial 4.0

International Licence (CC BY-NC 4.0).

\begin{abstract}
Objective: This research is aimed at determining the changes in individuals' knowledge, attitudes and behaviours regarding oral health in terms of nutritional habits, daily oral care and the provision of dental services during the quarantine process in the Coronavirus disease-19 (COVID-19) pandemic.

Materials and Methods: A total of 1010 volunteers (age $>18$ ) participated in this online survey which was designed to evaluate the participants' demographic information, oral hygiene habits, experiences about oral health and nutritional trends throughout the lockdown period of the COVID-19 pandemic.

Results: According to the dietary habits scores, there was a tendency towards dietary consumption that would positively affect oral health $(0.381 \pm 1.76)$ (mean \pm standard deviation). During this period, $11.4 \%$ of women and $20.2 \%$ of men smoked less. The frequency of brushing teeth in 20.6\% of the participants, flossing in $9.4 \%$ and using mouthwash in $28.7 \%$ increased. Moreover, the frequency of brushing teeth, flossing and using mouthwash in 7.8\%, 7.1\% and 7.5\% of the participants, respectively, decreased. $67.8 \%$ of the participants believed that oral health and general health were related to each other, and $80.5 \%$ thought that there was a risk of transmission of COVID-19 in dental treatment. Oral health problem was experienced in $21.7 \%$ of the participants during the COVID-19 pandemic. Finally, according to our survey, $25.6 \%$ of these people visited the dentist, while $74.4 \%$ did not.

Conclusion: During the quarantine period, positive changes were observed in individuals' nutrition and smoking behavior. Due to the pandemic, individuals who had oral health problems had reservations about seeking treatment, and treatment services were disrupted. It would be beneficial to increase the public's awareness about the re-planning of dental treatment services due to the pandemic conditions, and the measures taken for the protection of oral health.
\end{abstract}

Öz

Amaç: Bu araştırmada Koronavirüs hastalığı-19 (COVID-19) salgınında uygulanan karantina sürecinde ağız ve diş sağlığıyla ilgili olarak beslenme alışkanlıkları, günlük ağız bakımı ve diş hekimliği hizmetlerinin sunumu açısından bireylerin bilgi, tutum ve davranışlarındaki değişikliklerin tespit edilmesi amaçlanmaktadır. 
Gereç ve Yöntemler: Araştırma 18 yaş üzeri 1010 gönüllü ile çevrimiçi anket yoluyla yapılmıştır. Anket katılımcıların demografik bilgilerini, COVID-19 salgını esnasında uygulanan karantina dönemindeki beslenme eğilimlerini, ağız hijyeni alışkanlıkları ile ağız ve diş sağlığı ile ilgili deneyimlerini değerlendirmek üzere planlanmıştır.

Bulgular: Beslenme alışkanlıkları puanlamasına göre ağız ve diş sağlığına olumlu yönde etki edecek beslenme tüketimine doğru bir yönelme vardır $(0,381 \pm 1,76)$ (ortalama \pm standart sapma). Kadınların \%11,4'ü, erkeklerin \%20,2'si bu süreçte daha az sigara içmiştir. Katılımcıların \%20,6'sının diş fırçalama, \%9,4'ünün diş ipi, \%28,7'sinin ağız gargarası kullanım sıklığı artmış, \%7,8'inin diş fırçalama, \%7,1'inin diş ipi, \%7,5'inin ağız gargarası kullanım sıklığı azalmıştır. Katılımcıların \%67,8'i ağız ve diş sağlığı ile genel sağlığın ilişkili olduğu, \%80,5'i diş tedavisinde COVID-19 bulaşma riski olduğu görüşündedir. Katılımcıların \%21,7'si COVID-19 sürecinde ağız ve diş sağlığı ile ilgili bir sorun yaşamıştır. Bu kişilerin \%25,6'sı yaşadıkları sorun nedeniyle diş hekimine başvururken, \%74,4'ü başvurmamıştır.

Sonuç: COVID-19 salgınında uygulanan karantina döneminde bireylerin beslenme ve sigara içme davranışlarında olumlu yönde değişiklikler olmuştur. Ağız bakım alışkanlıklarında ise olumlu ve olumsuz yönde farklı eğilimler sergilenmiştir. Bu dönemde ağız ve diş sağlığı ile ilgili sorun yaşayan bireylerin salgın nedeniyle tedavi arayışına girmekte çekinceleri olmuş ve tedavi hizmetleri aksamıştır. Diş tedavi hizmetlerinin salgın şartlarına göre yeniden planlanmasının ve ağız sağlığının korunması için alınacak bireysel önlemler hakkında toplumda farkındalık oluşmasına yönelik çalışmaların artması faydalı olacaktır.

\section{Introduction}

The Coronavirus disease-19 (COVID-19) outbreak started in Wuhan, China, in December 2019, has become a significant public health problem for all countries in the world in a short time (1). On January 30, 2020, The World Health Organization (2) declared this outbreak to be an alarming public health emergency on an international level and recognized it as a pandemic on March 11.2020 (3). The first COVID-19 case was reported in Turkey on March 10.2020 (4) and social isolation to prevent the spread of the outbreak in this period and various measures have been conducted.

The fact that dentistry produces a large amount of aerosols and involves close contact with patients during treatment increases the risk of transmission of respiratory COVID-19 infection, which poses a risk to the dentist and assistants $(5,6)$. Therefore, as of April 1.2020, the COVID-19 Scientific Advisory Board of the Turkish Ministry of Health defined emergency practices in dentistry. The postponement of other treatments was suggested, and some dentists interrupted their work life in this process (7).

Calls to stay at home and curfew restrictions to control the pandemic and prevent the spread of the virus caused the disruption of people's regular activities in their home and work lives and limited social relations (8). Such unusual conditions may lead to depression and stress (9); people may prefer to consume high-calorie and high-sugar foods and beverages to feel better (10). However, the preference for such foods poses a risk to oral health (11).
Oral health, which has been shown to be related to many systemic diseases, is an integral part of general health $(12,13)$. Today, oral health is considered an indicator of individual and social health and quality of life; the definition of oral health is not only having healthy teeth, but is made in many ways (14). The current definition of oral health includes the fact that oral health is versatile, and that there is no infection or tissue loss. In addition, it includes speech, smile, smell, taste, touching, chewing, swallowing, as well as facial expressions, enabling us to convey our emotions without pain or discomfort (15). This definition is very comprehensive, and it is vital in ensuring that the quality of life that oral health is not limited to the oral cavity but affects our goodness and health very closely.

Awareness of individual routines, such as wellbalanced nutrition and optimum oral hygiene, is essential to maintain good oral health. Dietary consumption and frequency of fermented carbohydrates, acidic foods, and beverages should be under control (16). Brushing teeth with a fluoride toothpaste and using dental floss are the most essential practices to ensure oral hygiene, and the use of antimicrobial mouthwashes is also recommended $(17,18)$. Moreover, smoking is known to be a threat to oral health (19) and makes it difficult to treat patients with COVID-19 (20).

The importance of nutritional preferences and oral hygiene practices comes to the fore when the risk of getting COVID-19 infection is high due to the close relationship between oral health and general health. In the present study, we aimed to report personal 
experiences into scientific data by identifying changes in individuals' knowledge, attitudes, and behaviors regarding oral health in the quarantine process during the COVID-19 outbreak.

\section{Materials and Methods}

The present cross-sectional study was approved by the Ethics Committee on Science, Social and NonInterventional Health Sciences Research of İstanbul Yeni Yuzyıl University (protocol no: 2020/06-466), and data collection was carried out between 06/18/2020 and 06/30/2020 via an online Google survey. Inclusion criteria were volunteers over the age of 18 who could use the internet and wanted to participate in the survey. The survey consisted of the demographic information of the participants, nutritional trends in the period of COVID-19, oral hygiene habits, and experiences about oral health.

\section{Statistical Analysis}

The data obtained from the survey were analyzed with IBM SPSS V23. Compatibility with normal distribution was examined with the KolmogorovSmirnov test. A chi-square test was used to compare categorical variables according to the groups. Questions 2-6 were scored as " $+1,0,-1$ " to evaluate positive or negative changes in dietary habits in terms of oral health. The results were expressed as mean and standard deviation (sd) and median [minimum (min)maximum (max)] for quantitative data, and frequency (percent) for categorical data. The significance level was $p<0.05$.

\section{Results}

1010 people participated in the survey from Turkey's 71 cities. The demographic features of the participants are shown in Table 1 . The findings of nutritional habits during the COVID-19 pandemic are shown in Table 2. As a result of the scoring related to nutritional habits, the average nutritional score of the participants was $0.3381 \pm 1.76$ (mean $\pm \mathrm{sd}$ ), and the median was $0(-5-5)$ (min-max). According to the average nutritional score, there was a tendency towards dietary consumption positively affecting oral health (Figure 1).

Smoking habits were shown to vary depending on gender through the period evaluated $(p<0.001)$. While $78.4 \%$ of women did not smoke, the rate was $56 \%$ for men. $11.4 \%$ of women and $20.2 \%$ of men stated that they smoked less during this period. Smoking status varies depending on marital status $(p=0.017) .72 .2 \%$ of married people, $62.7 \%$ of divorced people, and $61.7 \%$ of single people did not smoke. Smoking did not vary depending on other conditions $(p>0.050)$ (Table 3).

$71.6 \%$ of the participants stated that there was no change in their brushing habits during the COVID-19 period whereas $20.6 \%$ stated that they brushed their teeth more frequently, and $7.8 \%$ decreased the frequency of brushing. $28.3 \%$ of participants used dental floss. The rate of dental floss usage of healthcare professionals (63.6\%) was higher than in other professions (24.1\%). Dental floss usage was also higher among those with postgraduate education (48.9\%) compared to individuals with other education levels including primary education (17.7\%), high school (19.6\%), associate's degree (24.8\%), and those with a license $(34 \%)(p<0.001)$. In this study, $7.1 \%$ of those using dental floss decreased their floss usage,

\begin{tabular}{|c|c|c|}
\hline & Frequency (n) & Percent (\%) \\
\hline \multicolumn{3}{|l|}{ Gender } \\
\hline Female & 580 & 57.4 \\
\hline Male & 430 & 42.6 \\
\hline \multicolumn{3}{|l|}{ Age } \\
\hline $61-70$ & 31 & 3.1 \\
\hline $51-60$ & 140 & 13.9 \\
\hline $41-50$ & 306 & 30.3 \\
\hline $31-40$ & 253 & 25.0 \\
\hline $18-30$ & 280 & 27.7 \\
\hline \multicolumn{3}{|l|}{ Marital status } \\
\hline Married & 687 & 68.0 \\
\hline Single & 264 & 26.1 \\
\hline Divorced & 59 & 5.8 \\
\hline \multicolumn{3}{|l|}{ Education status } \\
\hline Master and doctorate & 141 & 14.0 \\
\hline License & 297 & 29.5 \\
\hline Associate degree & 141 & 14.0 \\
\hline High school & 280 & 27.8 \\
\hline Primary education & 147 & 14.6 \\
\hline \multicolumn{3}{|l|}{ Occupation } \\
\hline Healthcare professionals & 107 & 10.6 \\
\hline Other professionals & 903 & 89.4 \\
\hline
\end{tabular}


In this period, I pay more attention to healthy eating

Fruit and vegetable consumption

Water consumption

Acidic beverage consumption

Consumption of bakery products such as bread, pastry and dessert
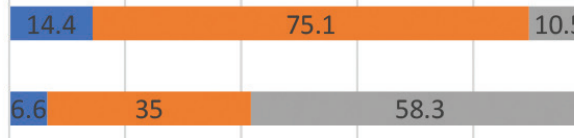

35

5.7
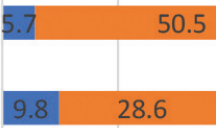

28.6
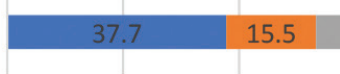

$\begin{array}{rrrrrrr}0 & 20 & 40 & 60 & 80 & 100 & 120 \\ \square(-) & \square(+) & \square & 0\end{array}$

Figure 1. Clustered bar graph of cases that would affect oral health positively and negatively

\begin{tabular}{|c|c|c|}
\hline & Frequency (n) & Percent (\%) \\
\hline \multicolumn{3}{|c|}{ Question 1. In the pandemic process, please mark the options appropriate for eating and drinking status* } \\
\hline I eat more in this process & 324 & 32.2 \\
\hline I eat less during this process & 117 & 11.6 \\
\hline I am snacking all day long & 113 & 11.2 \\
\hline There was no change in my eating and drinking habits & 516 & 51.2 \\
\hline \multicolumn{3}{|c|}{ Question 2. In this process, fruit and vegetable consumption } \\
\hline There was no change & 589 & 58.3 \\
\hline Decreased & 67 & 6.6 \\
\hline Increased & 354 & 35 \\
\hline \multicolumn{3}{|c|}{ Question 3. In this process, the consumption of bakery products such as bread, pastry, and dessert } \\
\hline There was no change & 472 & 46.7 \\
\hline Decreased & 157 & 15.5 \\
\hline Increased & 381 & 37.7 \\
\hline \multicolumn{3}{|l|}{ Question 4. In this process, consumption of acidic beverage } \\
\hline There was no change & 622 & 61.6 \\
\hline Decreased & 289 & 28.6 \\
\hline Increased & 99 & 9.8 \\
\hline \multicolumn{3}{|l|}{ Question 5. In this process, the consumption of water } \\
\hline There was no change & 442 & 43.8 \\
\hline Decreased & 58 & 5.7 \\
\hline Increased & 510 & 50.5 \\
\hline \multicolumn{3}{|c|}{ Question 6. In this period, I pay more attention to healthy eating } \\
\hline No & 145 & 14.4 \\
\hline Yes & 759 & 75.1 \\
\hline I have no idea & 106 & 10.5 \\
\hline
\end{tabular}


while $9.4 \%$ increased, and $83.5 \%$ did not change their floss usage.

The mouthwash use rate was $32.8 \% .7 .5 \%$ of the users stated that mouthwash usage decreased in this process, $28.7 \%$ increased, and $63.8 \%$ stated that there was no change in usage habits.

$67.8 \%$ of the participants thought that oral health, dental health, and general health were related to each other. While $90.7 \%$ of healthcare professionals agreed with this idea, only $65.1 \%$ of those who belonged to other professions agreed with this idea $(p<0.001)$. According to the state of having any general health problem, there was no statistically significant difference between the distribution of the level of knowledge about whether there was a relationship between oral health and general health ( $p>0.050$ ) (Table 4). $80.5 \%$ of the participants thought that there was a risk of COVID-19 transmission in dental treatment. This thought varied depending on the profession. $98.1 \%$ of healthcare professionals and $78.4 \%$ of other professional groups thought that there was a risk of COVID-19 transmission in dental treatment $(p<0.001)$.

$21.7 \%$ of the participants experienced a problem with oral health during the COVID-19 process. $36.1 \%$ of those who had oral health problems $(n=219)$ had

\begin{tabular}{|c|c|c|c|c|c|c|}
\hline & Not smoke & No change & More smoke & Less smoke & Test statistics & $\mathbf{p}$ \\
\hline \multicolumn{7}{|l|}{ Gender } \\
\hline Female & $455(78.4)^{a}$ & $46(7.9)^{\mathrm{a}}$ & $13(2.2)^{\mathrm{a}}$ & $66(11.4)^{a}$ & \multirow{2}{*}{$\chi 2=59.743$} & \multirow{2}{*}{$<0.001$} \\
\hline Male & $241(56)^{b}$ & $74(17.2)^{b}$ & $28(6.5)^{b}$ & $87(20.2)^{b}$ & & \\
\hline \multicolumn{7}{|l|}{ Education status } \\
\hline Master and doctorate & $108(73.5)$ & $16(10.9)$ & $2(1.4)$ & $21(14.3)$ & \multirow{5}{*}{$x^{2}=16.164$} & \multirow{5}{*}{0.184} \\
\hline License & $186(66.4)$ & $30(10.7)$ & $14(5)$ & 50 (17.9) & & \\
\hline Associate degree & $97(68.8)$ & $18(12.8)$ & $7(5)$ & $19(13.5)$ & & \\
\hline High school & $192(64.6)$ & $40(13.5)$ & $14(4.7)$ & $51(17.2)$ & & \\
\hline Primary education & $110(78)$ & $16(11.3)$ & $3(2.1)$ & $12(8.5)$ & & \\
\hline \multicolumn{7}{|l|}{ Occupation } \\
\hline Healthcare professionals & $75(70.1)$ & 17 (15.9) & $2(1.9)$ & $13(12.1)$ & \multirow{2}{*}{$x 2=3.766$} & \multirow{2}{*}{0.288} \\
\hline Other professionals & $621(68.8)$ & $103(11.4)$ & $39(4.3)$ & $140(15.5)$ & & \\
\hline \multicolumn{7}{|l|}{ Marital status } \\
\hline Married & $496(72.2)^{c}$ & $72(10.5)$ & $24(3.5)$ & $95(13.8)$ & \multirow{3}{*}{$\chi 2=15.525$} & \multirow{3}{*}{0.017} \\
\hline Single & $37(62.7)^{c d}$ & $12(20.3)$ & $1(1.7)$ & $9(15.3)$ & & \\
\hline Divorced & $163(61.7)^{d}$ & 36 (13.6) & $16(6.1)$ & 49 (18.6) & & \\
\hline Total & 696 (68.9) & 120 (11.9) & $41(4.1)$ & $153(15.1)$ & & \\
\hline
\end{tabular}

Table 4. Distribution of responses related to the relationship between oral health and general health

\begin{tabular}{|c|c|c|c|c|c|}
\hline & Wrong & Right & No idea & Test statistics & $\mathbf{p}$ \\
\hline \multicolumn{6}{|l|}{ Occupation } \\
\hline Healthcare professionals & $3(2.8)$ & $97(90.7)^{\mathrm{a}}$ & $7(6.5)^{a}$ & \multirow{2}{*}{$x 2=29.222$} & \multirow{2}{*}{$<0.001$} \\
\hline Other professionals & $44(4.9)$ & $588(65.1)^{b}$ & $271(30)^{b}$ & & \\
\hline \multicolumn{6}{|c|}{ Have any general health problems } \\
\hline No & $18(4.6)$ & $266(68.2)$ & $106(27.2)$ & \multirow{2}{*}{$x 2=0.043$} & \multirow{2}{*}{0.979} \\
\hline Yes & $29(4.7)$ & $419(67.6)$ & $172(27.7)$ & & \\
\hline Total & $47(4.7)$ & $685(67.8)$ & $278(27.5)$ & & \\
\hline
\end{tabular}


a mild toothache, $24.2 \%$ had tooth sensitivity, $22.4 \%$ had a severe toothache, $16.9 \%$ had cracked or broken teeth, $13.7 \%$ had swelling, $12.3 \%$ had lost a posterior filling, $12.3 \%$ had slight bleeding in the mouth area, $9.1 \%$ had loss of a permanent bridge or crown, and $8.2 \%$ had loss of a temporary filling or crown.

While $25.6 \%(n=56)$ of people with oral health problems during the COVID-19 process visited the dentist, $74.4 \%(n=163)$ did not. $58.3 \%$ of the participants who did not visit the dentist stated that they did not want to leave the house due to the virus. $44.8 \%$ stated that they were afraid of getting infected during dental treatment, and $40.5 \%$ thought that health institutions were risky. $19 \%$ stated that their dentist did not accept them, and 16\% did not visit the dentist for economic reasons. The problems experienced by patients who did not visit the dentist are given in Table 5 .

Among the people who had oral health problems during the COVID-19 pandemic, $66.1 \%$ of the 56 people who tried could easily reach a dentist, while 32.1 could not. $36.4 \%$ of the patients went to the public hospital for treatment, $32.7 \%$ to a private practice, and $12.7 \%$ to health institutions such as hospitals, medical centers, or outpatient centers. $5.5 \%$ went to the university hospital and $5.4 \%$ met with dentists over the phone. The patients with oral health problems who visited a dentist are listed in Table 6 . While $67.3 \%$ of the people going to the dentist stated that dentists could only perform emergency treatments, $12.7 \%$ stated

Table 5. Distribution of oral and dental health problems experienced by patients who did not apply to the dentist

\begin{tabular}{|l|l|l|}
\hline & Frequency (n) & Percent (\%) \\
\hline Mild toothache & 66 & 40.5 \\
\hline Tooth sensitivity & 47 & 28.8 \\
\hline Filling fall out & 30 & 27.3 \\
\hline Cracked or broken tooth & 29 & 17.8 \\
\hline Severe toothache & 26 & 16 \\
\hline Swelling & 21 & 12.9 \\
\hline Mild bleeding in the mouth area & 20 & 12.3 \\
\hline Falling out of permanent bridge or crown & 15 & 9.2 \\
\hline Falling out of temporary filling or crown & 14 & 8.6 \\
\hline Prosthesis incompatibility & 3 & 1.8 \\
\hline Other & 82 & 50.2 \\
\hline *Multiple answers & & \\
\hline
\end{tabular}

Table 6. Distribution of oral health problems experienced by patients applying to the dentist

\begin{tabular}{|l|l|l|}
\hline \multicolumn{1}{|l}{ Severe toothache } & Frequency (n) & Percent (\%) \\
\hline Mild toothache & 23 & 41.1 \\
\hline Swelling & 13 & 23.2 \\
\hline Cracked or broken tooth & 9 & 16.1 \\
\hline Falling filling & 8 & 14.3 \\
\hline Mild bleeding in the mouth area & 7 & 12.5 \\
\hline Tooth sensitivity & 7 & 12.5 \\
\hline Falling out of permanent bridge or crown & 6 & 10.7 \\
\hline Falling out of temporary filling or crown & 5 & 8.9 \\
\hline Other & 4 & 7.1 \\
\hline *Multiple answers & 26 & 46.5 \\
\hline
\end{tabular}


that they would not be able to do any treatment, while $10.9 \%$ were offered other non-emergency treatments, but not emergency treatments. $72.7 \%$ of patients who visited dental treatment institutions observed that more importance was given to hygiene due to the pandemic; $14.5 \%$ stated that they did not see a difference.

\section{Discussion}

During the COVID-19 pandemic process, the time spent at home increased due to the calls to stay at home and the curfews instituted to prevent the spread of the outbreak. It was observed that there was no change in eating and drinking patterns of $51.2 \%$ of the participants from 71 provinces in Turkey. This result is compatible with Scarmozzino and Visioli's (21) studies in Italy regarding the nutritional habits during the quarantine period (49.6\%). Frequent snacking is one of the dietary habits that negatively affect oral health (22). In our study, the rate of individuals who stated that they had a snack during the day in the quarantine period was $11.2 \%$. This rate was $51.8 \%$ in the study conducted in Poland (23). While the proportion of participants who did not change the consumption of carbohydrate-weighted products during the quarantine period was $46.7 \%, 37.7 \%$ stated that they consumed this type of food more often. $58 \%$ of the participants stated that there was no change in their fruit and vegetable consumption, $6.6 \%$ decreased, and $35 \%$ increased. In the studies of Scarmozzino and Visioli (21), it was observed that the foods they call "comfort food" such as sweets and chocolate were consumed by $42.5 \%$ and salty snacks by $23.5 \%$ more. In the same study, it was observed that $69.2 \%$ of the individuals did not change their consumption of vegetables and fruits, while $21.2 \%$ increased. In our study, according to the average healthy nutrition score obtained by scoring nutritional habits, it was seen that there was a nutritional tendency that should positively affect oral health in the quarantine period. In our study, it was determined that $31.1 \%$ of the participants were smokers. This rate was $40 \%$ for men and $21.6 \%$ for women. According to the 2012 Turkey Statistics Institute (TUIK) data, the proportion of people using tobacco and tobacco products in Turkey was $27 \%, 13.1 \%$ in women, and $41.4 \%$ in men (24). In this study, we could not obtain any information about tobacco products other than cigarettes. However, it was seen that smoking was slightly higher than the usage rates of tobacco and tobacco products reported in the TUIK data.

The smoking rate in married people was lower than among singles. During COVID-19, 38\% of the participants who smoked stated that the amount of smoking did not change, while $13 \%$ stated that they smoked more; $48.7 \%$ smoked less. In Poland' study, it was shown that $40 \%$ of smokers did not change the amount of smoking, while $45.2 \%$ smoked more (23). In our study, the rate of participants who stated that they smoked more was found to be lower than that of this study, and that the rate of those who reduced their amount of smoking was high. Medical professionals have stated the importance of healthy eating to making the immune system stronger since the beginning of the COVID-19 pandemic. They have also emphasized that the COVID-19 infection significantly affects the lungs and that smoking affects the prognosis of the disease negatively. We think that individuals who internalize the warnings about this issue positively changed their food preferences and smoking behavior.

When the toothbrushing habit was examined, it was seen that $71.6 \%$ of the participants did not change their brushing habits, $20.6 \%$ brushed their teeth more frequently and $7.8 \%$ less frequently. In our study, the proportion of participants using dental floss was $28.3 \%$. This rate was $28.6 \%$ in South America (25), $16.8 \%$ in Iran (26), $11.8 \%$ in Kuwait (27), and 11\% in Denmark (28). $7.1 \%$ of those using dental floss decreased their usage, while $9.4 \%$ increased. The dental floss usage rate is higher in health staff than in other occupational groups, and the dental floss usage rate of those who have graduate education was higher than individuals at other education levels. Mouthwash use rate was $32.8 \%$. $7.5 \%$ of the users stated that mouthwash use decreased and $28.7 \%$ increased in this process. Our study shows that there were individuals with positive and negative changes in oral care habits in the quarantine process. It is thought that changing daily life routines may have affected oral care habits in this period. In addition, stress levels can increase during pandemic periods, and psychological disorders such as depression and anxiety can be observed (9). One of them is health anxiety. Health anxiety is a condition that occurs when one interprets the changes in the body as a symptom of being sick (29). This anxiety 
is experienced to some extent by everyone, and this anxiety contributes to pay attention more (30). However, in cases where health anxiety is high, no changes were seen in healthy living indicators such as healthy eating, attention to sleep, exercising, and smoking compared to those without health anxiety. Similarly, low levels of health anxiety may cause the person to not pay attention to their health and to not continue their health-related behaviors (31). Based on this information, it is thought that individuals' health anxiety levels may play a role in the changes in nutrition, smoking, and oral care habits during the COVID-19 pandemic. We think that measuring the relationship between health anxiety levels and these factors may contribute to future studies in the literature.

$67.8 \%$ of the participants thought that there was a relationship between oral health and general health, while $27.5 \%$ stated that there was no relationship. It is thought that awareness on this issue is related to education. Awareness level was higher among graduate-school educated and healthcare professionals. Zulfiqar et al. (32) also showed that medical school students' oral health awareness was higher than students in other faculties. The level of knowledge on this subject did not differ in individuals with any general health problems from those without general health problems. In some studies, the awareness of individuals with systemic disease about the relationship between oral health and general health was low (33-37). Considering that individuals with chronic diseases are more at risk for COVID-19 infection (38), we think that low awareness of oral health will further increase this population's health risks.

In previous studies, it was shown that the first reason for visiting the dentist was pain. $9 \%$ visited the dentist for only control without a complaint (39), and $84.4 \%$ (40) said, "I do not go to the dentist unless obliged to do so." In this period, it was determined that the COVID-19 outbreak was a factor that prevented patients from seeking treatment. It was seen that individuals were worried about the risk of virus infection within health institutions and during dental procedures and were reluctant to leave the house. $80.5 \%$ of the participants thought that there was a risk of COVID-19 transmission during dental treatment. The level of awareness of health professionals regarding this issue was significantly higher than that of other professionals. $98.1 \%$ of healthcare professionals knew that there was a risk of transmission of COVID-19 infection during dental treatment. $80 \%$ of patients who contacted dental treatment institutions observed that more emphasis was placed on hygiene due to COVID-19. In this period, some of the dentists did not accept patients due to the risk of COVID-19 infection, which led to a disruption of the dental treatment of the patients. $16 \%$ of the patients who did not visit the dentist experienced problems such as severe toothache (16\%), swelling $(12.9 \%)$, loss of a temporary filling or cap $(8.6 \%)$. $5.6 \%$ of the participants who had any oral problems did not contact a treatment institution. Although the patients who visited dental clinics experienced urgent problems, such as severe toothache $(41.1 \%)$ and swelling (16\%), some patients saw the dentist due to non-emergency situations, such as mild toothache (23.2\%), mild bleeding in the mouth (12.5\%), and tenderness (10\%). In a study conducted in China, Guo et al. (41) found that the number of patients receiving treatment at dental institutions decreased by $38 \%$ with the onset of the pandemic, and the most common reason for treatment was pain and swelling related to pulpal and periapical lesions.

In our study, $32.1 \%$ of 55 people who looked for treatment related to oral health stated that they could not easily reach a dentist. $5.4 \%$ of the participants received information about their problems by making phone calls with their dentists, except for patients who contacted different institutions of the state and private sector. $67.3 \%$ of the dentists stated that they could only perform emergency treatments, while $12.7 \%$ said that they could not do any treatment. $10.9 \%$ of them offered their patients other non-urgent procedures. During the COVID-19 process, patients had difficulties in reaching the dentist, and the treatment requests of the patients who could reach a dentist were selectively met according to their urgency. Considering the presence of patients who had any dental problems and could not seek treatment with various concerns, it is thought that telecommunication practices should be at the forefront in these periods and possible future epidemics (42).

With the widespread practice of telemedicine, it will be possible to question the patients' urgency situations before providing care and, if necessary, 
to make recommendations or direct them to the treatment institutions by sharing images. In this way, it will be easier to resolve the patients' problems, and the risk of spreading the infection will decrease by decreasing the accumulation in health institutions (43-45).

Our study shows that dentistry services are disrupted due to virus-related causes in the COVID-19 process. It is not possible to say that this disruption will cause socially permanent negativity in oral and dental health, considering the three months from March 10.2020, when the first case was announced, to the time of the survey. However, due to limited data on the COVID-19 virus, no precise prediction can be made about how long the outbreak will last (46). Oral health is related to general health, and they share and affect each other with non-communicable diseases such as cancer, diabetes, respiratory tract, and cardiovascular diseases $(12,13)$. It is also known that COVID-19 infection progresses more severely in individuals with chronic disease (38). Therefore, during a long-term epidemic, the health of individuals both who are healthy or have chronic diseases might have a worsening oral health which appears to be a disadvantage in terms of COVID-19 infection.

\section{Conclusion}

In the quarantine period applied after the onset of the COVID-19 pandemic, there were positive changes in individuals' nutrition and smoking behavior. In this period, there were different positive and negative trends in oral care habits. It has been determined that individuals who have oral health problems during the quarantine have reservations about treatment due to the COVID-19 outbreak, and there are disruptions not only in emergency treatments but also in routine dental treatment services. Considering the relationship between oral health and general health, we think it will be beneficial to plan dental treatment services according to the current situation and increase the awareness of the individual measures to be taken to protect oral health.

\section{Ethics}

Ethics Committee Approval: The present crosssectional study was approved by the Ethics Committee on Science, Social and Non-Interventional Health Sciences Research of İstanbul Yeni Yuzyıl University (protocol no: 2020/06-466), and data collection was carried out between $06 / 18 / 2020$ and $06 / 30 / 2020$ via an online Google survey.

Informed Consent: Inclusion criteria were volunteers over the age of 18 who could use the internet and wanted to participate in the survey.

\section{Authorship Contributions}

Peer-review: Internally and externally peerreviewed.

Concept: Z.H.K., Design: Z.H.K., Supervision: H.Ş.S., Data Collection or Processing: Z.H.K., Analysis or Interpretation: H.Ş.S., Literature Search: Z.H.K., Critical Review: H.S.S., Writing: Z.H.K.

Conflict of Interest: No conflict of interest was declared by the authors.

Financial Disclosure: The authors declared that this study received no financial support.

\section{References}

1. Phelan AL, Katz R, Gostin LO. The Novel Coronavirus Originating in Wuhan, China: Challenges for Global Health Governance. JAMA 2020; 323: 709-10.

2. Mahase E. China coronavirus: WHO declares international emergency as death toll exceeds 200. BMJ 2020; 368: m408. Published 2020 Jan 31.

3. World Health Organization. Rolling updates on corona virüs disease (COVID-10). 2020. Last Accessed Date: 31.07.2020. Available from: https://www.who.int/emergencies/diseases/ novel-coronavirus-2019/events-as-they-happen.

4. World Health Organization. Corona virüs disease (COVID-2019) situation reports. 2020. Available from: https://www.who. int/emergencies/diseases/novel-coronavirus-2019/situationreports.

5. Ge ZY, Yang LM, Xia JJ, Fu XH, Zhang YZ. Possible aerosol transmission of COVID-19 and special precautions in dentistry. $J$ Zhejiang Univ Sci B 2020; 21: 361-8.

6. Meng L, Hua F, Bian Z. Coronavirus disease 2019 (COVID-19): Emerging and future challenges for dental and oral medicine. $J$ Dent Res 2020; 99: 481-7.

7. Türk Diş Hekimleri Birliği, Diş hekimliğinde güncellenmiş acil uygulamalar. Available from: URL: http://www.tdb.org.tr/ Evrak/06042020/Genelge_2020_001-1.689.pdf

8. Zhang J, Wu W, Zhao X, Zhang W. Recommended psychological crisis intervention response to the 2019 novel coronavirus pneumonia outbreak in China: a model of West China Hospital. Precis Clin Med 2020; pbaa006.

9. Xiang YT, Yang Y, Li W, Zhang L, Zhang Q, Cheung T, et al. Timely mental health care for the 2019 novel coronavirus outbreak is urgently needed. Lancet Psychiatry 2020; 7: 228-9.

10. Yılmaz C, Gökmen V. Neuroactive compounds in foods: Occurrence, mechanism and potential health effects. Food Res Int 2020; 128: 108744. 
11. Pflipsen $M$, Zenchenko $\mathrm{Y}$. Nutrition for oral health and oral manifestations of poor nutrition and unhealthy habits. Gen Dent 2017; 65: 36-43.

12. Dörfer C, Benz C, Aida J, Campard G. The relationship of oral health with general health and NCDs: a brief review. Int Dent J 2017; 67 (Suppl 2): 14-8.

13. Kanjirath PP, Kim SE, Rohr Inglehart M. Diabetes and oral health: the importance of oral health-related behavior. J Dent Hyg 2011; 85: 264-72.

14. Patrick DL, Lee RS, Nucci M, Grembowski D, Jolles CZ, Milgrom $P$. Reducing oral health disparities: a focus on social and cultural determinants. BMC Oral Health 2006; 6(Suppl 1): S4.

15. FDI. FDI's definition of oral health. Available from: https://www. fdiworlddental.org/oral-health/fdi-definition-of-oral-health

16. Gondivkar SM, Gadbail AR, Gondivkar RS, Sarode SC, Sarode GS, Patil S, et al. Nutrition and oral health. Dis Mon 2019; 65: 147-54.

17. Choo A, Delac DM, Messer LB. Oral hygiene measures and promotion: review and considerations. Aust Dent J 2001; 46: 166-73.

18. Lang NP, Cumming BR, Löe H. Toothbrushing frequency as it relates to plaque development and gingival health. J Periodontol 1973; 44: 396-405.

19. Agnihotri R, Gaur S. Implications of tobacco smoking on the oral health of older adults. Geriatr Gerontol Int 2014; 14: 526-40.

20. Vardavas Cl, Nikitara K. COVID-19 and smoking: A systematic review of the evidence. Tob Induc Dis 2020; 18: 20.

21. Scarmozzino F, Visioli F. Covid-19 and the subsequent lockdown modified dietary habits of almost half the population in an Italian sample. Foods 2020; 9: 675.

22. Erdem AP, Sepet E, Sabuncu H, Özcan I, Erdem TL. Determining the future caries development in different caries risk groups. J Istanb Univ Fac Dent 2011; 45: 19-27.

23. Sidor A, Rzymski P. Dietary Choices and Habits during COVID-19 Lockdown: Experience from Poland. Nutrients 2020; 12: E1657.

24. TÜiK, Türkiye İstatistik Kurumu Başkanlığı, Küresel yetişkin tütün araşttrması, 2012. Available from: URL: http://tuik.gov.tr/ PreHaberBultenleri.do?id=13142

25. Gómez MV, Toledo A, Carvajal P, Gomes SC, Costa RSA, Solanes $\mathrm{F}$, et al. A multicenter study of oral health behavior among adult subjects from three South American cities. Braz Oral Res 2018; 32: e22.

26. Asgari F, Majidi A, Koohpayehzadeh J, Etemad K, Rafei A. Oral hygiene status in a general population of Iran, 2011: a key lifestyle marker in relation to common risk factors of non-communicable diseases. Int J Health Policy Manag 2015; 4: 343-52.

27. Al-Shammari KF, Al-Ansari JM, Al-Khabbaz AK, Dashti A, Honkala EJ. Self-reported oral hygiene habits and oral health problems of Kuwaiti adults. Med Princ Pract 2007; 16: 15-21.

28. Christensen LB, Petersen PE, Krustrup U, Kjøller M. Self-reported oral hygiene practices among adults in Denmark. Community Dent Health 2003; 20: 229-35.

29. Asmundson GJ, Abramowitz JS, Richter AA, Whedon M. Health anxiety: current perspectives and future directions. Curr Psychiatry Rep 2010; 12: 306-12.

30. Asmundson GJG, Taylor S. How health anxiety influences responses to viral outbreaks like COVID-19: What all decision- makers, health authorities, and health care professionals need to know. J Anxiety Disord 2020; 71: 102211.

31. Schütte K, Vocks S, Waldorf M. Fears, Coping Styles, and Health Behaviors: A Comparison of Patients With Hypochondriasis, Panic Disorder, and Depression. J Nerv Ment Dis 2016; 204: 77886.

32. Zulfiqar R, Rasheed HU, Haide SA. Comparison of oral healthrelated knowledge, attitude and behavior among medical and non-medical categories of students of Lahore, Punjab-Pakistan. ASDS 2019; 3: 154-8.

33. Al Habashneh R, Khader Y, Hammad MM, Almuradi M. Knowledge and awareness about diabetes and periodontal health among Jordanians. J Diabetes Complications 2010; 24: 409-14.

34. Poudel P, Griffiths R, Wong VW, Arora A, Flack JR, Khoo CL, et al. Oral health knowledge, attitudes and care practices of people with diabetes: a systematic review. BMC Public Health 2018; 18 : 577.

35. Kumar A, Rai A. Oral health status, health behaviour and treatment needs of patients undergoing cardiovascular surgery. Braz J Cardiovasc Surg 2018; 33: 151-4.

36. Sanchez P, Everett B, Salamonson Y, Ajwani S, Bhole S, Bishop J, et al. Oral health and cardiovascular care: Perceptions of people with cardiovascular disease. PLoS One 2017; 12: e0181189.

37. Sanchez P, Everett B, Salamonson Y, Redfern J, Ajwani S, Bhole $S$, et al. The oral health status, behaviours and knowledge of patients with cardiovascular disease in Sydney Australia: a crosssectional survey. BMC Oral Health 2019; 19: 12.

38. Guan WJ, Liang WH, Zhao Y, Liang HR, Chen ZS, Li YM, et al. Comorbidity and its impact on 1590 patients with COVID-19 in China: a nationwide analysis. Eur Respir J 2020; 55: 2000547.

39. Oktay I, Saydam GB, Doğan F. Sıfir çürük hayal mi?. Türk Dişhekimleri Birliği Derg 2004; 79: 43-6.

40. Hayran O, Sur H, Mumcu G, Gemlik N, İşçi E, Şişman N ve ark. Sağlık Bakanlığı ve SSK tarafindan verilen ağız ve diş sağlığı hizmetlerinden yararlanma ve hasta memnuniyeti araştirması. İstanbul; Türk Diş Hekimleri Birliği Yayınları Araştırma Dizisi 2: 2008. Available from: URL: http://www.tdb.org.tr/tdb/v2/ yayinlar/Arastirma_Dizisi/arastirmadizisi_6.pdf

41. Guo H, Zhou Y, Liu X, Tan J. The impact of the COVID-19 epidemic on the utilization of emergency dental services [published online ahead of print, 2020 Mar 16]. J Dent Sci 2020; doi: 10.1016/j. jds.2020.02.002.

42. Emami E. COVID-19: Perspective of a dean of dentistry. JDR Clin Trans Res 2020; 5: 211-3.

43. Machado RA, de Souza NL, Oliveira RM, Martelli Júnior $H$, Bonan PRF. Social media and telemedicine for oral diagnosis and counselling in the COVID-19 era. Oral Oncol 2020; 105: 104685.

44. Naqvi K, Mubeen SM, Ali Shah SM. Challenges in providing oral and dental health services in COVID-19 pandemic. J Pak Med Assoc 2020; 70(Suppl 3): S113-7.

45. Pereira LJ, Pereira CV, Murata RM, Pardi V, Pereira-Dourado SM. Biological and social aspects of Coronavirus Disease 2019 (COVID-19) related to oral health. Braz Oral Res 2020; 34: e041.

46. Dziedzic A, Wojtyczka R. The impact of coronavirus infectious disease 19 (COVID-19) on oral health [published online ahead of print, 2020 Apr 18]. Oral Dis 2020; 10.1111/odi.13359. 